\title{
Utilization of an in vitro assay to evaluate chromatin degradation by candidate apoptotic nucleases
}

\author{
Francis M. Hughes $\mathrm{Jr}^{1}$ and John A. Cidlowski
}

Laboratories of Integrative Biology, National Institute of Environmental Health Sciences, Research Triangle Park, NC, USA

1 corresponding author: NIEHS, P.O. Box 12233, MD E2-02, Research Triangle Park, NC 27709, USA. tel: 919-541-0788; fax: 919-541-1367; e-mail:

Hughes4@niehs.nih.gov

Received 10.7.96; revised 20.10.96; accepted 22.10.96

Edited by G Melino

\begin{abstract}
Apoptosis is commonly associated with the catabolism of the genome in the dying cell. The chromatin degradation occurs in essentially two forms: (1) internucleosomal DNA cleavage to generate oligonucleosomal-length fragments $(180-200 \mathrm{bp}$ and multiples thereof), and (2) cleavage of higher order chromatin structures to generate $\approx 30-50 \mathrm{~Kb}$ fragments. To investigate this component of apoptosis and identify the nuclease(s) responsible, we have developed and utilized an in vitro assay that recapitulates the genomic destruction seen during apoptosis in vivo and allows the simultaneous analysis of both forms of DNA degradation from the same sample. Using this assay we evaluated the digestion patterns of several candidate apoptotic nucleases: DNase I, DNase II, and cyclophilin (NUC18) as well as the bacterial enzyme micrococcal nuclease (not thought to be involved in apoptosis). Chromatin degraded by DNase I formed a smear of DNA on conventional static-field agarose gels and $\approx 30$ $50 \mathrm{~Kb}$ DNA fragments on pulsed field gels. In contrast, DNase II, at a physiologically relevant $\mathrm{pH}$, had no effect on the integrity of HeLa chromatin in either analysis. Similar to DNase I, cyclophilin C produced only $\approx 30-50 \mathrm{~Kb}$ DNA fragments but did not generate internucleosomal fragments. In contrast, micrococcal nuclease generated both oligonucleosomal and $\approx 30-50 \mathrm{~Kb}$ DNA fragments. Nuclear extracts from glucocorticoid-treated apoptotic thymocytes generated oligonucleosomal DNA fragments and the larger $\approx 30-50 \mathrm{~Kb}$ DNA fragments, fully recapitulating both types of apoptotic DNA degradation. Previously, differential sensitivity of nucleases to inhibition by $\mathrm{Zn}^{2+}$ was used to argue that two distinct enzymes mediate $\approx 30-50 \mathrm{~Kb}$ DNA cleavage and internucleosomal DNA degradation. While, the nuclease activity present in thymocyte nuclear extracts was differentially sensitive to inhibition by $\mathrm{Zn}^{2+}$ during short term incubations it was not during prolonged digestions, suggesting that differences in DNA detection are likely to account for previous results. Together our studies show that none of the nucleases commonly associated with apoptosis could fully recapitulate the DNA degradation seen in vivo.
\end{abstract}

Keywords: apoptosis, cell death, endonuclease, nuclease assay

Abbreviations: MARS, matrix attachment regions; MN, micrococcal nuclease; TE buffer, Tris, EDTA buffer; TPE buffer, Tris, Phosphate, EDTA buffer

\section{Introduction}

Recently much attention has been focused on the process of apoptosis or programmed cell death. Correct implementation of this death process is critical to many physiological phenomena such as development, immune function and tissue homeostasis. In addition to its role in normal physiology, deregulation of apoptosis appears to play a central role in many pathological phenomena including AIDS, cancer and neurodegenerative diseases such as Alzheimer's (Häcker and Vaux, 1995). Thus an understanding of this process may lead to novel and innovative avenues for therapeutic intervention in disease.

Apoptosis is characterized by several well-defined morphological and biochemical hallmarks. Morphologically the cells shrink, the chromatin condenses around the periphery of the nucleus and the entire cell eventually buds into small spherical strutures known as apoptotic bodies which contain organelles, fragments of the nucleus and other cytoplasmic components. Membrane changes facilitate the rapid endocytosis of these dying cells and apoptotic bodies by neighboring cells or resident macrophages wherein they are completely degraded and their components recycled. Many biochemical changes are associated with these morphological alterations and much controversy exists over which of these changes are part of the common pathway of apoptosis. By far the most widely recognized biochemical change associated with the vast majority of apoptotic systems is the degradation of genomic DNA in the internucleosomal or linker DNA regions (Bortner et al, 1995; Hughes and Cidlowski, 1994; Schwartzman and Cidlowski, 1993a; Wyllie, 1980). Cleavage in these regions releases DNA of nucleosomal or oligonucleosomal lengths which, when analyzed by conventional static-field agarose electrophoresis, forms a very definitive banding pattern known as the 'apoptotic ladder'. This pattern of DNA fragmentation occurs prior to morphological changes and has been suggested to be the first irreversible event in the death process (Arends et al, 1990; Compton and Cidlowski, 1986; McConkey et al, 1989a).

Although initially observed in conventional gels (Kokileva, 1979), the recent application of pulsed field electrophoretic techniques to the study of apoptosis has led to the identification of an additional form of genomic degradation (into $\approx 30-50 \mathrm{~Kb}$ DNA fragments) associated with dying cells (Cohen et al, 1994; Oberhammer et al, 1993; Walker 
et al, 1993). These fragments have been hypothesized to arise from the cleavage of higher order chromatin configurations known as 'loops' (Filipski et al, 1990; Kokileva, 1994; Oberhammer et al, 1993; Walker et al, 1995) that are presumed to be attached to the nuclear matrix through $\mathrm{A}-\mathrm{T}$ rich regions known as matrix attachment regions (MARs) (Laemmli et al, 1992; Mirkovich et al, 1984; Saitoh and Laemmli, 1994). These $\approx 30-$ $50 \mathrm{~Kb}$ DNA fragments have been proposed to be generated by cleavage at or near the MARs and have been proposed to provide the substrate for subsequent internucleosomal cleavage (Kokileva, 1994; Walker et al, 1993), however, no definitive cleavage site or substrate-product relationship has been shown. The enzyme(s) responsible for this type of chromatin cleavage are unknown and a current topic of debate is whether the two forms of DNA degradation are mediated by separate or identical enzymes. Several studies have attempted to differentiate the activities of these nucleases, primarily on the basis of their ionic requirements and sensitivities to inhibitors. For example, recent studies in both thymocytes (Brown et al, 1993; Kokileva, 1995) as well as isolated liver nuclei (Kokileva, 1995; Walker et al, 1994) have reported that the generation of oligonucleosomal fragments was more sensitive to inhibition by $\mathrm{Zn}^{2+}$ than was the cleavage of chromatin into $\approx 30-50 \mathrm{~Kb}$ DNA fragments. These data were used to infer the existence of separate nucleases mediating the different forms of DNA degradation, and further, that the large fragments were substrate for internucleosomal cleavage enzymes. Similarly, others have suggested that the generation of $\approx 30-50 \mathrm{~Kb}$ DNA fragments is dependent only on $\mathrm{Mg}^{2+}$, whereas further degradation to oligonucleosomal DNA fragments required both $\mathrm{Ca}^{2+}$ and $\mathrm{Mg}^{2+}$ (Cain et al, 1994; Sun and Cohen, 1994; Walker et al, 1994, 1995).

Additional forms of DNA cleavage into even larger fragments (such as $\approx 300 \mathrm{~Kb}$ fragments) have also been detected in some models of apoptosis. From these studies, a stepwise degradation of chromatin was proposed in which successively smaller fragments of DNA (each representing a progressively smaller structure of chromatin) are generated from their larger predecessors (Cain et al, 1995; Kokileva, 1994; Walker et al, 1995). However, unlike the $\approx 30-50 \mathrm{~Kb}$ DNA fragments, such very large fragments are not consistently observed in all apoptotic cells, are dependent on the cell type as well as inducing agent, and may even be reversible (Beere et al, 1995; Bortner et al, 1995; Cohen et al, 1994; Oberhammer et al, 1993; Ormerod et al, 1994; Walker et al, 1994).

The study of DNA degradation during apoptosis has benefited from several in vitro models (Cohen and Duke, 1984; Hewish and Burgoyne, 1973; Lazebnik et al, 1993; McConkey et al, 1989b; Nieto and Lopez-Rivas, 1989; Sun et al, 1994; Walker et al, 1994) which have provided a wealth of information on internucleosomal cleavage and, recently, on the generation of large fragments. Similarly, our laboratory previously developed an in vitro assay (the HeLa nuclei assay) designed to measure the internucleosomal cleavage activity associated with these dying cells (Schwartzman and Cidlowski, 1991, 1993b). In the current study we have modified and extended the use of this assay to simultaneously analyze chromatin degradation into fragments ranging from $10-500 \mathrm{~Kb}$. Specifically, we evaluated the degradation patterns evoked by several nucleases proposed to mediate DNA degradation during apoptosis. These include DNase I (Peitsch et al, 1993, 1994), DNase II (Barry and Eastman, 1993; Eastman, 1994) and cyclophilin (related to NUC18) (Montague et al, 1994, 1996). We have also studied micrococcal nuclease (MN), which, though not implicated in apoptosis, specifically cleaves chromatin at internucleosomal regions and thus generates an oligonucleosomal ladder indistinguishable from that produced during apoptosis in vivo. Finally, we examined the ability of nuclear extracts from apoptotic thymocytes to produce $\approx 30-50 \mathrm{~Kb}$ DNA and oligonucleosomal DNA fragments and the sensitivity of their production to inhibition by $\mathrm{Zn}^{2+}$.

\section{Results}

Previous studies from our laboratory have shown that HeLa nuclei make an excellent source of substrate for the analysis of internucleosomal DNA cleavage activity because the cells are highly resistant to apoptosis and the isolated nuclei do not spontaneously degrade (i.e. autodigest) their DNA internucleosomally even in the presence of exogenous $\mathrm{Ca}^{2+}$ or $\mathrm{Mg}^{2+}$ (Schwartzman et al, 1991, 1993b). However, it has been suggested that other cells can autodigest their DNA into large $(\approx 30-50 \mathrm{~Kb})$ fragments without generating internucleosomal fragments (Walker et al, 1994). Therefore, to determine if HeLa nuclei are a suitable substrate to use in an assay for the generation of large DNA fragments, we examined the integrity of their DNA over time in the absence of added nuclease. As shown in Figure 1, HeLa chromatin was not degraded into either low (Figure 1A) or high (Figure 1B) molecular weight fragments, even up to $5 \mathrm{~h}$ of incubation, although some signal was lost from the pulsed field plugs over time. The intensity of the compression band on the pulsed field gel (unresolved
A

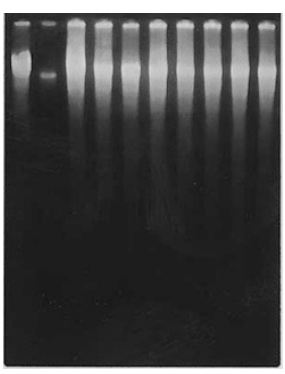

0.25 .5 .7511 .52345 Hours

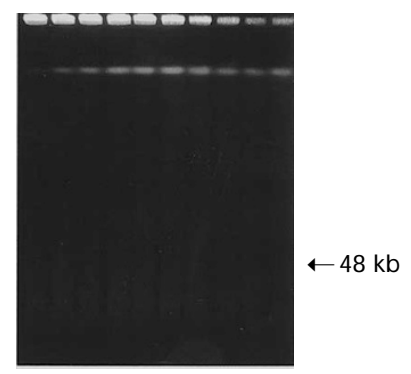

0.25 .5 .7511 .52345

Hours
Figure 1 Autodigestion of HeLa nuclei. HeLa nuclei were incubated in the presence of $2 \mathrm{mM} \mathrm{MgCl}_{2}$ and $1 \mathrm{mM} \mathrm{CaCl}_{2}$ for increasing periods of time. At the indicated time, samples were divided and aliquots processed for conventional or pulsed field analysis as described in Materials and Methods. (A) Ethidium bromide-stained agarose gel of HeLa DNA subjected to conventional staticfield electrophoresis. (B) Ethidium bromide-stained agarose gel of HeLa DNA, from the same samples as in $A$, subjected to pulsed field electrophoresis. 
DNA $>500 \mathrm{~Kb}$ ) is slightly increased over time suggesting that there is a small amount of endogenous nuclease activity. This slight degradation can be prevented by the inclusion of EDTA (data not shown), implicating the involvement of specific, divalent cation-dependent enzymes in the generation of this background degradation. The limited amount of degradation is significantly below the level of total genomic catabolism this assay is designed to detect and therefore should not interfere with interpretation of the results.

We have utilized this assay to explore the patterns of DNA degradation evoked by nucleases proposed to mediate DNA degradation during apoptosis. DNase I is one such candidate nuclease (Boone et al, 1995; Peitsch et al, 1993, 1994) and Figure 2(A and B) depicts the pattern of both low and high molecular weight DNA fragments generated by $100 \mathrm{ng}$ DNase I in this asssay. DNase I degraded HeLa chromatin in a time-dependent fashion, generating a smear of low molecular weight DNA fragments on a conventional agarose gel (Figure 2A). These results are consistent with previously published data (Peitsch et al, 1993; Vanderbilt et al, 1982). Pulse field analysis of these same samples (Figure 2B) allowed the detection of larger forms of fragmentation in which chromatin is degraded from intact chromosomes (which remain in the preparatory agarose plugs) through a continuum of sizes that eventually center on $\approx 30-50 \mathrm{~Kb}$ and become nearly undetectable thereafter. This pattern is similar to that seen in thymocyte nuclei induced to undergo autodigestion by addition of $\mathrm{Ca}^{2+}$ and $\mathrm{Mg}^{2+}$ and thymocyte autodigestion is a well characterized model thought to accurately reflect the DNA degradation seen during apoptosis (Cohen et al, 1984; Hewish et al, 1973; McConkey et al, 1989b; Nieto et al, 1989; Sun et al, 1994; Walker et al, 1994). Loss of signal on these gels indicates degradation of DNA into $<2 \mathrm{~Kb}$ fragments which diffuse out of the preparatory agarose plug during processing. These results demonstrate that DNase I can produce high molecular weight apoptoticlike $\approx 30-50 \mathrm{~Kb}$ DNA fragments although the low molecular weight analysis reveals a smear of DNA not generally associated with the apoptotic process.

DNase II has also been proposed as a candidate apoptotic nuclease (Barry et al, 1993; Eastman, 1994). Although the $\mathrm{pH}$ optimum of DNase II is 5.5 , the most extreme acidic conditions an apoptotic cell could be expected to achieve is 6.3 (Barry et al, 1993). Thus $\mathrm{pH} 6.3$ was used in this experiment to more accurately reflect the possible in vivo situation. In addition, an increased amount of DNase II was used to provide similar units of activity (at an optimal $\mathrm{pH}$ ) as compared to DNase I. As seen in Figure 2, very little or no chromatin degradation was detected during the course of this experiment on either conventional (Figure 2C) or pulsed field gels (Figure 2D). In the pulsed field analysis a slight increase in the intensity of the compression band was detected which is probably attributable to endogenous HeLa activities observed in the absence of divalent cation chelation (Figure 1). The results
A

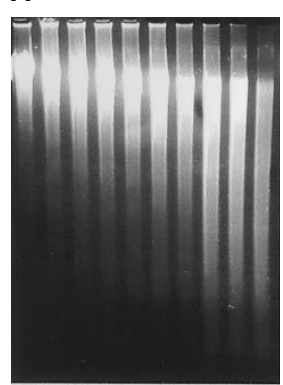

0.25 .5 .7511 .52345

Hours

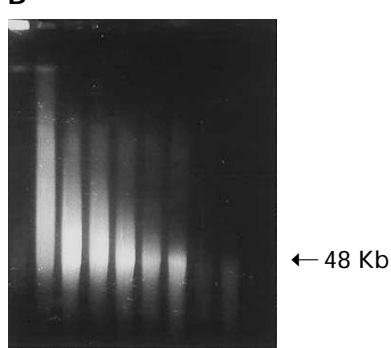

0.25 .5 .7511 .52345

Hours
C

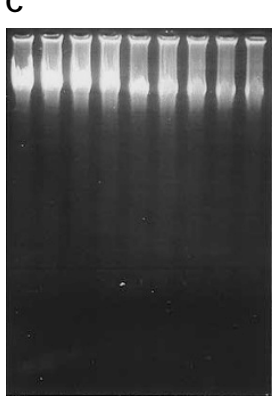

0.25 .5 .7511 .52345

Hours

D

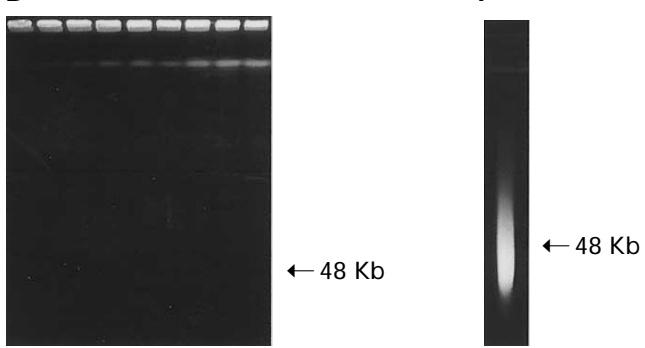

0.25 .5 .7511 .52345

Hours

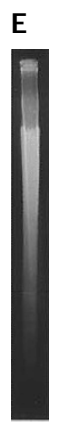

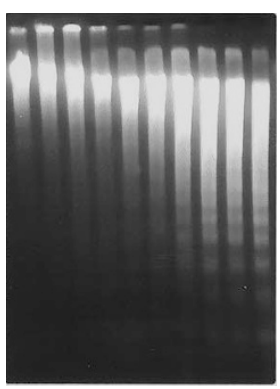

0.25 .5 .7511 .52345

Hours

H

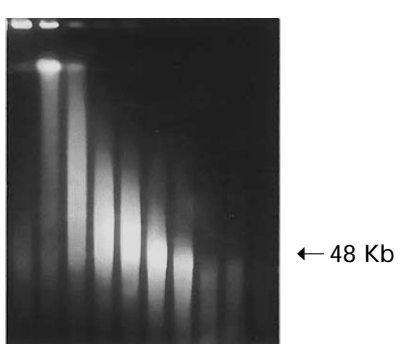

0.25 .5 .7511 .52345

Hours

Figure 2 HeLa nuclei assay performed as in Figure 1 in the presence of $50 \mathrm{ng}$ DNase I ( $\mathrm{A}$ and $\mathrm{B}), 100 \mathrm{ng} \mathrm{DNase} / \mathrm{II}(\mathrm{C}$ and D), $3.5 \mu \mathrm{g}$ cyclophilin C (E and F) or $1 \mathrm{ng}$ micrococcal nuclease $(G$ and $H)$. DNase I: $(A)$ Conventional agarose gel of HeLa DNA isolated at the indicated time periods. (B) Pulsed field agarose gel of HeLa DNA from the same samples as in A. DNase II: (C) Conventional agarose gel. (D) Pulsed field agarose gel. Cyclophilin C: (E) Conventional agarose gel. (F) Pulsed field agarose gel. Micrococcal nuclease: (G) Conventional agarose gel. (H) Pulsed field agarose gel. 
of this assay suggest that DNase II, at a physiologically relevant $\mathrm{pH}$, does not possess sufficient activity to evoke the type of catastrophic genomic degradation seen during apoptosis.

Our laboratory has previously isolated an $18 \mathrm{Kd}$ nuclease (NUC18) active in apoptotic thymocytes but only present in control cells in an inactive high molecular weight complex (Gaido and Cidlowski, 1991). Sequencing of fragments of this enzyme revealed a high homology with the cyclophilin family of immunophilins. Subsequent analysis revealed that the three members of this family (Cyclophilins A, B and C) have significant nuclease activity with cyclophilin $\mathrm{C}$ being the most potent (Montague et al, 1994). In the present study we evaluated the effects of the most active homologue of cyclophilin (cyclophilin $\mathrm{C}$ ) on HeLa nuclear chromatin integrity. A single time point $(5 \mathrm{~h})$ was chosen because of the limited supply of pure enzyme. As shown in Figure 2E, cyclophilin $\mathrm{C}$ did not produce any specific low molecular weight DNA fragments, although there was a slight increase in DNA smearing compared to the time 0 control. Similarly, cyclophilin A does not produce internucleosomal fragments (data not shown). Cyclophilin $\mathrm{C}$ did, however, generate a very strong $\approx 30-50 \mathrm{~Kb}$ DNA signal during the incubation (Figure 2F). The results indicate that cyclophilins are unlikely to be involved in the production of internucleosomal DNA fragments during apoptosis but may mediate the generation of $\approx 30-50 \mathrm{~Kb}$ DNA fragments. Similar results are being reported in an additional manuscript on the nuclease activities of cyclophilin (Montague et al, 1996). Together the results indicate that none of the enzymes proposed to mediate DNA fragmentation during apoptosis can completely recapitulate all the DNA degradation seen in apoptotic cells in vivo.

Next we investigated the effects of micrococcal nuclease $(\mathrm{MN})$. Although this bacterial enzyme has not been implicated in apoptosis, it is well known to cleave chromatin in the internucleosmal regions and generate a DNA ladder equal to that seen during apoptosis. As shown in Figure 2G, $1 \mathrm{ng} M N$ degraded the HeLa chromatin in a time dependent fashion, generating an apoptotic-like oligonucleosomal DNA ladder within $2 \mathrm{~h}$ of incubation. In the pulsed field analysis (Figure $2 \mathrm{H}$ ) $\mathrm{MN}$ generates a pattern similar to DNase I in that it rapidly degrades all the intact chromatin into a continuum of sizes and finally to $\approx 30-50 \mathrm{~Kb}$ DNA fragments before becoming absent from
A

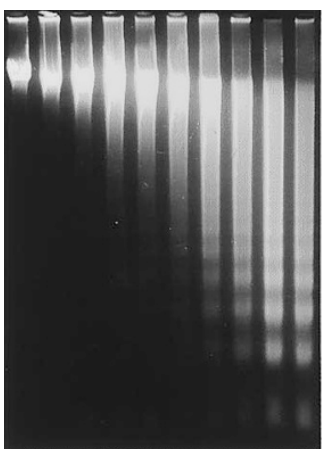

$0.25 .5 .7511 .523 \quad 4 \quad 5$ Hours

B

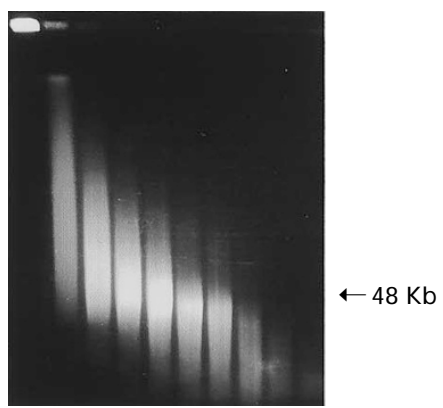

0.25 .5 .7511 .52345 Hours
C

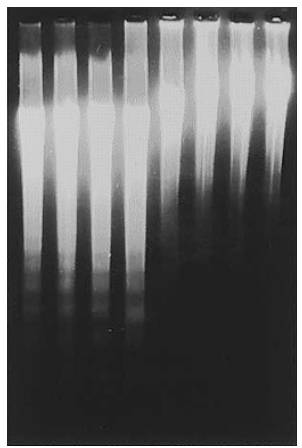

$0 \quad 1510501005001000$ $\mu \mathrm{M} \mathrm{Zn}^{2+}$

D

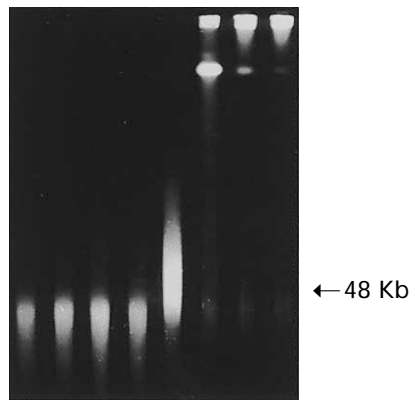

$0 \quad 1510501005001000$ $\mu \mathrm{M} \mathrm{Zn}^{2+}$
E

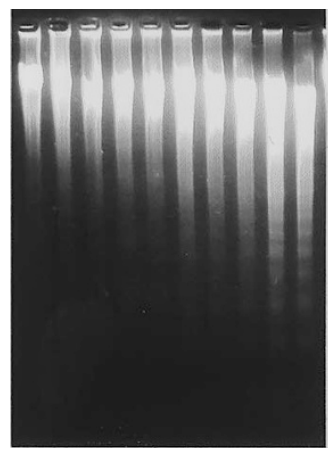

$0.25 .5 .7511 .523 \quad 45$ Hours

F

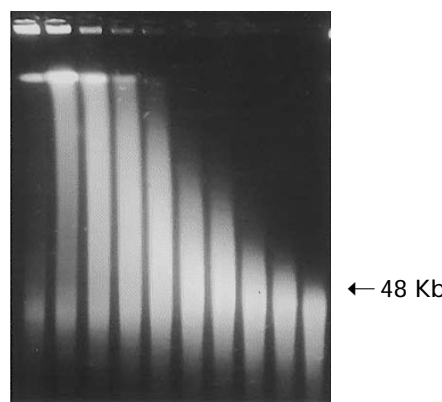

0.25 .5 .7511 .52345 Hours

Figure 3 HeLa nuclei assay performed as in Figure 1 in the presence of $100 \mu$ g thymocyte nuclear extract either alone (A and B), with increasing concentrations of

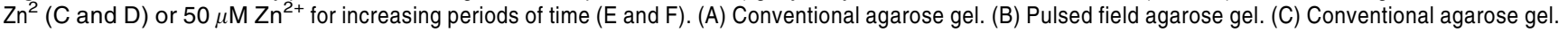
(D) Pulsed field agarose gel. (E) Conventional agarose gel. (F) Pulsed field agarose gel. 
the gel completely. Thus, the single enzyme MN, generates both oligonucleosomal and $\approx 30-50 \mathrm{~Kb}$ DNA fragments, suggesting that a single enzyme can mediate both types of DNA degradation. These results do not, however, rule out the potential involvement of different nucleases mediating each type of DNA degradation during apoptosis in vivo, but only suggest that one enzyme can generate both types of DNA degradation.

We have previously shown that nuclear extract from apoptotic thymocytes can also generate internucleosomal
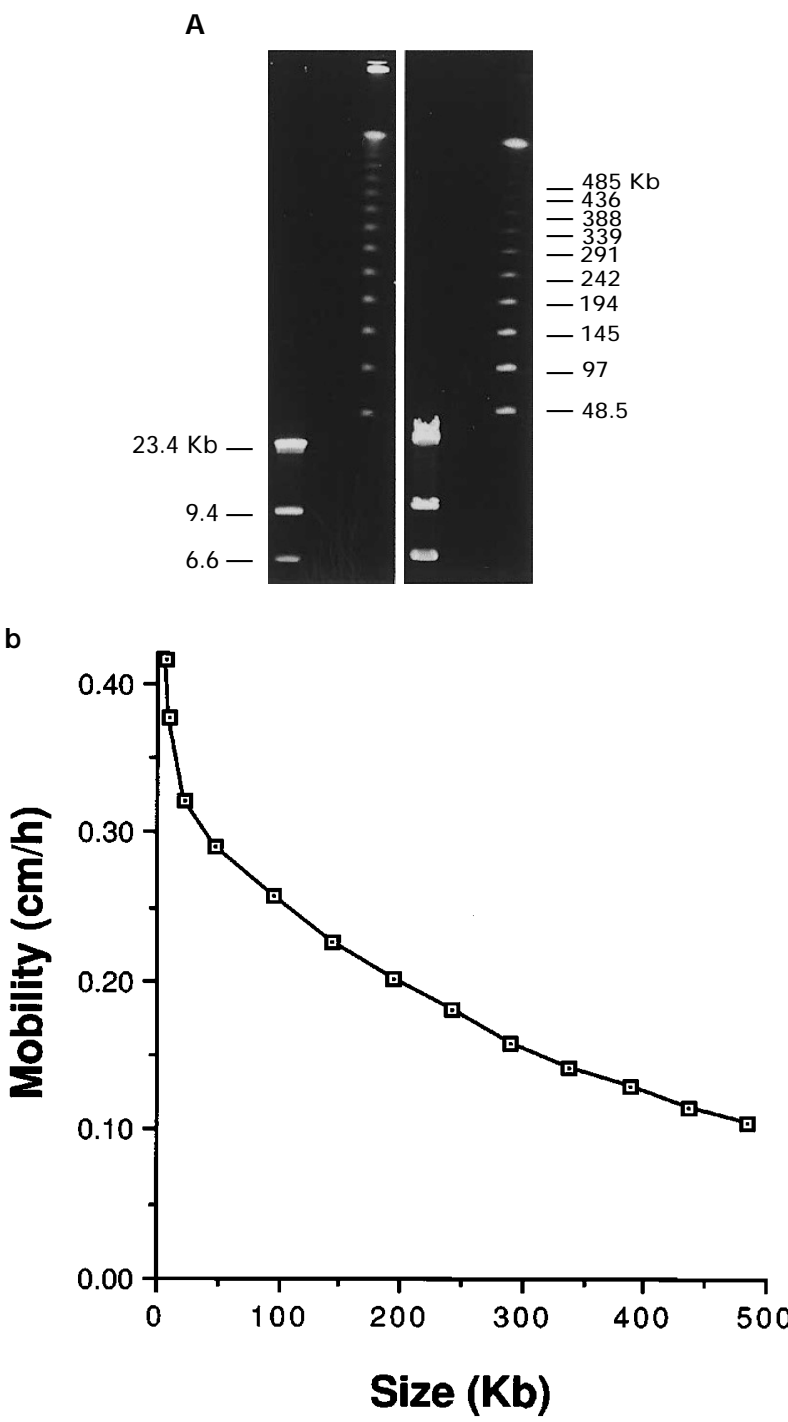

Figure 4 Molecular weight standards for pulsed field electrophoresis. DNA fragments obtained from a HinD III digest of $\lambda$ DNA (lanes 1 and 3 ) or concatamers of the intact $\lambda$ genome were used as size standards. Prior to electrophoresis, one set of standards (lanes 1 and 2) were encapsulated in agarose and processed in an identical manner as sample plugs as a control for the diffusion of fragments out of the sample plugs and electrophoresis off the end of the gel. (A) Pulsed field agarose gel showing the migration of standards. Lane 1 (HinD III digest of $\lambda$ DNA) and 2 ( $\lambda$ concatamers) were first encapsulated in agarose and treated as described above. Lanes 3 and 4 are non-processed standards. (B) The standards shown in A were graphed according to their mobility $(\mathrm{cm} / \mathrm{h})$ as a function of their size. From the resulting graph, the linear range of size separation can be directly read off $(50-500 \mathrm{~Kb})$.
DNA fragments in this assay. We next sought to determine if such extracts could also produce the large $\approx 30-50 \mathrm{~Kb}$ DNA fragments. As shown in Figure $3 \mathrm{~A}$, treatment of HeLa nuclei with $100 \mu \mathrm{g}$ nuclear extract resulted in a significant time-dependent degradation of the HeLa genome into oligonucleosomal DNA fragments. Pulsed field analysis (Figure 3B) revealed a fragment pattern similar to DNase I, cyclophilin $\mathrm{C}$ and $\mathrm{MN}$ in which there was rapid degradation of HeLa chromatin to $\approx 30-50 \mathrm{~Kb}$ fragments which eventually become almost completely absent from the gel. Thus, activity(s) in nuclear extract from apoptotic thymocytes generates both types of apoptotic-like DNA fragments (oligonucleosomal and $\approx 30-50 \mathrm{~Kb}$ ), essentially recapitulating the in vivo patterns of genomic degradation.

Recently, other investigators have reported that, in intact thymocytes and nuclear autodigestion experiments, the generation of $\approx 30-50 \mathrm{~Kb}$ DNA fragments and oligonucleosomal DNA fragments is differentially sensitive to $\mathrm{Zn}^{2+}$ during short term incubations (Brown et al, 1993; Kokileva, 1995; Walker et al, 1994). They interpreted their data to mean that different enzymes mediate each form of DNA degradation. Figure $3 C$ and $D$ depicts the effects of increasing concentrations of $\mathrm{Zn}^{2+}$ on the degradation of HeLa chromatin by thymocyte nuclear extracts during short term digestions $(3 \mathrm{~h})$. Following this incubation, internucleosomal fragmentation remains clearly evident in the presence of $10 \mu \mathrm{M} \mathrm{Zn}^{2+}$ but is inhibited by $50 \mu \mathrm{M}$ or greater of this ion. The generation of $\approx 30-50 \mathrm{~Kb}$ DNA fragments

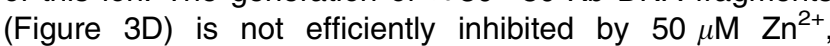
although the modal DNA fragment size is slightly shifted up in size (quantitative data not shown). However, the generation of $\approx 30-50 \mathrm{~Kb}$ DNA fragments is clearly inhibited at higher concentrations of $\mathrm{Zn}^{2+}(>100 \mu \mathrm{M})$. These results are consistent with the previously published literature (Brown et al, 1993; Kokileva, 1995; Walker et al, 1994) which suggests these two forms of DNA degradation are mediated by separate enzymes, differing in their sensitivity to $\mathrm{Zn}^{2+}$. However, when comparing pulsed field and conventional agarose gels, it should be noted that detection of large DNA fragments is considerably more sensitive than small fragments because of the increased number of ethidium bromide molecules each DNA fragment binds. Accordingly, the pulsed field and conventional gels cannot be directly compared because of the 150-250 fold difference in DNA fragment size. This, in conjunction with the substantially fewer number of cuts in a chromosome needed to detect a decrease in size on the pulsed field gel, makes the pulsed field analysis a significantly more sensitive measurement of nuclease activity than the conventional agarose gel. Because of this difference in sensitivity of detection of DNA fragments, the interpretation of the data derived from $\mathrm{Zn}^{2+}$ studies may be in question and the data of Figure $3 C$ and $D$ may have resulted from a partial inhibition of a single nuclease. If this hypothesis is correct, then extending the time of incubation in the

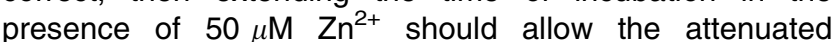
digestion reaction to go further toward completion, resulting in the delayed appearance of oligonucleosomal DNA fragments. Figure $3 \mathrm{E}$ and $\mathrm{F}$ shows the result of an extended digestion time course with nuclear extract in the 


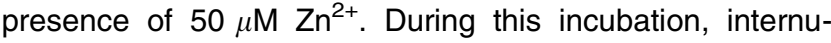
cleosomal DNA fragments became apparent (albeit weakly) by $4 \mathrm{~h}$ of incubation, suggesting that the internucleosomal enzyme was not completely inhibited by this treatment but only partially reduced in activity. Incubation with this ion also slowed the degradation seen on pulsed field gels (Figure 3F), further suggesting that the high molecular weight degradation was not mediated by a separate

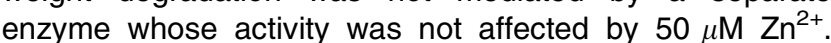
Taken together the results are consistent with a single, $\mathrm{Zn}^{2+}$ sensitive, nuclease mediating both types of DNA degradation by the nuclear extract.

\section{Discussion}

Apoptosis has recently been associated with the degradation of chromatin into large $(\approx 30-50 \mathrm{~Kb})$ DNA fragments in addition to the classical oligonucleosomal fragments often used as a hallmark of this process. In the present study we utilized an in vitro assay to examine the ability of several candidate nucleases to recapitulate both types of DNA degradation. DNase I reproduced the $\approx 30-50 \mathrm{~Kb}$ apoptotic-like DNA fragments but did not produce internucleosomal fragments. Likewise, cyclophilin C (related to NUC18) produced large $\approx 30-50 \mathrm{~Kb}$ DNA fragments but not internucleosomal fragments. In contrast, DNase II did not catalyze significant DNA fragmentation of any size. Interestingly, micrococcal nuclease was able to completely mimic both types of chromatin degradation, demonstrating that separate enzymes may not be necessary to generate both types of DNA degradation. These results do not, however, rule out the possibility that separate nucleases exist in vivo. Nuclear extracts from apoptotic thymocytes also produced both types of in vivo apoptotic DNA fragmentation, suggesting that these extracts possess all the enzymatic requirements for this process. Finally, although previous reports suggested that large fragment and small fragment generation were differentially sensitive to inhibition by $\mathrm{Zn}^{2+}$ (Brown, et al, 1993; Kokileva, 1995; Walker et al, 1994), extended digestions suggest that these results may reflect an inherent difference in the sensitivity of ethidium bromide staining of the large and small DNA fragments. Together the results are consistent with a single nuclease mediating the DNA degradation evoked by the thymocyte nuclear extracts.

Our results demonstrate that DNase I, cyclophilin C (related to NUC18), $\mathrm{MN}$ and thymocyte nuclear extract can all generate $\approx 30-50 \mathrm{~Kb}$ apoptotic-like DNA fragments, despite the radically different patterns produced on the conventional gels. The $\approx 30-50 \mathrm{~Kb}$ DNA fragments are postulated to result from cleavage of chromatin at or near the region attached to the nuclear matrix (the MARs) (Filipski et al, 1990; Kokileva, 1994; Oberhammer et al, 1993; Walker et al, 1995), although this selectivity has not been conclusively demonstrated. Such areas are known to be centers of active transcription and actively transcribed areas are preferentially susceptible to digestion by nucleases such as DNase 1 (Gromova et al, 1995). Thus it is possible that MARs, and the areas that surround them form natural hypersensitive sites. In this regard it is interesting that the generation of these large DNA fragments has also been detected in two separate studies of necrosis (Bicknell and Cohen, 1995; Kataoka et al, 1995) during which many nonspecific enzymes are activated.

DNA degradation during apoptosis has been proposed to occur stepwise, proceeding downward in size through a $\approx 300 \mathrm{~Kb}$ DNA species to the $\approx 30-50 \mathrm{~Kb}$ DNA fragments. However, many studies have not detected the $\approx 300 \mathrm{~Kb}$ fragments. Likewise, our analysis did not reveal any specific fragment bands larger than $\approx 30-50 \mathrm{~Kb}$, even though we significantly slowed the kinetics of the reaction in order to detect any such fragments that may transiently appear. Instead, we detect an initial smear of very large fragments which are rapidly degraded to $\approx 30-50 \mathrm{~Kb}$. We suspect that the early smear represents chromosomes that are in early stages of degradation. For example, if we assume that cleavage occurs at intervals of $\approx 30-50 \mathrm{~Kb}$, then a single cut in one chromosome would generate two large DNA fragments that average one-half of a chromosome in length. If the cut is chosen randomly the actual fragments generated would form a continuum of sizes (which constitute a smear) ranging from a single $\approx 30-$ $50 \mathrm{~Kb}$ DNA fragment to an intact chromosome minus $\approx 30-50 \mathrm{~Kb}$. As degradation continues the modal fragment size decreases rapidly to $\approx 30-50 \mathrm{~Kb}$. Interestingly, in vivo we and others detect only $\approx 30-50 \mathrm{~Kb}$ DNA fragments without an early smear (Bortner et al, 1995; Cohen et al, 1994; Oberhammer et al, 1993, 1994; Walker et al, 1994). We speculate that the lack of a detectable smear reflects the fact that, in vivo, a cell population undergoes apoptosis asynchronously with only a small number of cells showing characteristic apoptotic changes at any given time. Accordingly, at the onset of the experiment, most cells would have intact DNA, but a small number may be rapidly degrading their DNA through the continuum of sizes down to $\approx 30-50 \mathrm{~Kb}$ DNA fragments where they persist for a relatively longer period of time. During the period that these fragments persist, other cells may begin rapidly degrading their DNA down to $\approx 30-50 \mathrm{~Kb}$. Thus, the number of cells containing $\approx 30-50 \mathrm{~Kb}$ DNA fragments will increase over time while the number of cells possessing a smear of DNA sizes would remain exceedingly low and beyond the threshold of detection. This would give the appearance that $\approx 30-50 \mathrm{~Kb}$ DNA fragments are generated without any intermediate sizes. In contrast, in the HeLa nuclei assay all nuclei are acted upon simultaneously by the exogenous nuclease activity, causing a synchronized degradation of HeLa chromatin and making an early smear clearly apparent. Further evidence of the asynchronous nature of in vivo apoptosis versus the synchronous nature of the HeLa assay can be seen by examining DNA remaining in the preparatory agarose plugs. When $\approx 30-$ $50 \mathrm{~Kb}$ DNA fragments are seen in vivo, significant amounts of DNA remains in the plug (Bortner et al, 1995) indicating the presence of intact DNA from nondying cells. However, in the HeLa assay as the $\approx 30-50 \mathrm{~Kb}$ DNA fragments are formed, all signal has been lost from the plugs (Figures 2 and 3 ), demonstrating that the chromatin in all nuclei had been degraded. Thus the DNA smear we detect early in the synchronized HeLa assay may actually reflect the degradation pattern occurring asynchronously in a cell population. 
One interesting result of this study is that a single nuclease, such as MN, can generate both the $\approx 30-50 \mathrm{~Kb}$ apoptotic-like DNA fragments and oligonucleosomal fragments. Thus a single nuclease with an internucleosomal specificity could potentially mediate both types of DNA degradation during apoptosis. These results do not, however, rule out a separate $\approx 30-50 \mathrm{~Kb}$ DNA fragmentgenerating enzyme in apoptotic cells in vivo or in our thymocyte nuclear extracts, nor do they discount the possibility of more than one nuclease mediating either type of DNA fragmentation, rather they simply show that there is no physical need for multiple enzymes since one nuclease can generate both types of fragments. Analysis of types of nucleases involved in apoptosis and their specificities for chromatin structures is currently being investigated in our laboratory.

\section{Materials and Methods}

\section{Materials}

Micrococcal nuclease $(16,322$ Units/mg) was obtained from Worthington Biochemical Corp. (Freehold, NJ) while DNase I (1900 Units/mg), DNase II (900 Units/mg) and RNase A were purchased from Sigma Chemical Corp. (St. Louis, MO). Cyclophilin $\mathrm{C}$ was a generous gift from Sandoz Pharmaceuticals (Bazel, Switzerland). Dexamethasone was received from Steraloids (Wilton, $\mathrm{NH}$ ). Tris was obtained from Fisher Scientific (Norcross, GA) whereas EDTA was received from EM Science (Curtin Matheson Scientific, Houston, TX), chloroform from Mallinckrodt Chemicals (Paris, KY) and phenol from United States Biochemical (Cleveland, $\mathrm{OH}$ ). Proteinase $\mathrm{K}$ was purchased from Boehringer Mannheim (Indianapolis, IN) while Joklik's Minimum Essential Medium was obtained from Flow Laboratories (McLean, VA). Fetal calf serum was purchased from Irvine Scientific (Santa Ana, CA) and calf serum received from Intergen (Purchase, NY). Insert agarose from FMC Bioproducts (Rockland, ME). The HinD III digest of $\lambda$ DNA was obtained from Gibco/BRL (Gaithersburg, MD) while the $\lambda$ concatamers were purchased from New England BioLabs (Beverly, MA).

\section{HeLa nuclei assay}

The HeLa nuclei assay was modified from previously published accounts (Schwartzman et al, 1991, 1993b) to include analysis of large DNA fragments by pulsed field electrophoresis. Briefly, HeLa cells were maintained $\left(10^{5}-7 \times 10^{5} \mathrm{cells} / \mathrm{ml}\right)$ in suspension culture at $37^{\circ} \mathrm{C}$ in Joklik's minimum essential medium supplemented with $2 \%$ fetal calf serum, $2 \%$ calf serum, $2 \mathrm{mM}$ glutamine, $75 \mathrm{U} / \mathrm{ml}$ penicillin and $50 \mathrm{U} / \mathrm{ml}$ streptomycin sulfate. Prior to assay, cells were counted, pelleted and resuspended in $10 \mathrm{mM} \mathrm{MgCl}_{2}, 0.25 \%$ Nonidet $\mathrm{P}-40$ to isolate nuclei. Nuclei were then pelleted, resuspended in $50 \mathrm{mM}$ Tris $(\mathrm{pH} 7.4)$ and $2 \times 10^{6}$ nuclei added to $1.5 \mathrm{ml}$ microcentrifuge tubes containing final concentrations of $50 \mathrm{mM}$ Tris (pH 7.4 or 6.3 for DNase II), $2 \mathrm{mM}$ $\mathrm{MgCl}_{2}, 1 \mathrm{mM} \mathrm{CaCl}$ and experimental treatments in a total volume of $400 \mu \mathrm{l}$. The parameters of this assay have been previously optimized for the detection of internucleosomal cleavage activity (Schwartzman et al, 1991, 1993b). The effects of all nucleases on chromatin integrity were dose-dependent and the concentrations of active enzymes were chosen to provide similar amounts of DNA degradation during the course of the experiment.

DNA fragmentation during apoptosis in vivo is very rapid, requiring only 15-60 min. Because these changes occur in such a short period, the sequence of events has been difficult to evaluate. Thus, in the present studies the concentrations of enzyme under investigation were chosen to allow the reaction to occur over an extended period of time in order to facilitate data analysis. Preliminary experiments revealed that high concentrations of enzyme would lead to kinetics of DNA degradation comparable to that seen in vivo. In addition, the relatively low ionic strength conditions of the assay has been shown to allow degradation of both relaxed, transcriptionally active chromatin and bulk inactive chromatin (Walker and Sikorska, 1986).

For pulsed field analysis, $200 \mu \mathrm{l}$ was removed at the end of the incubation and mixed with $200 \mu \mathrm{l}$ of $1 \%$ Incert agarose at $37^{\circ} \mathrm{C}$ until nuclei were evenly dispersed. The mixture was transferred to a $0.5 \mathrm{~cm}^{2}$ mold and placed at $4{ }^{\circ} \mathrm{C}$ for $5 \mathrm{~min}$ to solidify. Agarose plugs were then extruded into $10 \mathrm{ml}$ of $100 \mathrm{mM}$ EDTA, $1 \%(\mathrm{w} / \mathrm{v}) \mathrm{N}$-lauroylsarcosine and incubated at $37^{\circ} \mathrm{C}$ overnight. Plugs were subsequently transferred to $1 \mathrm{ml}$ of the same buffer containing $100 \mu \mathrm{g}$ proteinase $\mathrm{K}$ and incubated a minimum of $16 \mathrm{~h}$ at $50^{\circ} \mathrm{C}$. No effects of longer incubations were noted. Plugs were stored at $4^{\circ} \mathrm{C}$ in this buffer until used.

Following removal of the aliquot for pulsed field analysis, conventional electrophoresis samples were prepared from the remaining nuclei by first adding EDTA, $\mathrm{NaCl}$ and sodium dodecyl sulfate to a final concentration of $25 \mathrm{mM}, 540 \mathrm{mM}$, and $0.5 \%$, respectively. The EDTA serves a dual purpose; to chelate divalent cations, effectively inhibiting cation-dependent nucleases, and to maximize the solubility of the released chromatin fragments (Walker et al, 1986). TE buffer (10 mM Tris (pH 7.4), 1 mM EDTA) was added to bring the final volume to $400 \mu \mathrm{l}$ and Proteinase $\mathrm{K}$ added to $0.5 \mathrm{mg} / \mathrm{ml}$. Samples were then incubated for $1 \mathrm{~h}$ at $50^{\circ} \mathrm{C}$, extracted twice with phenol/chloroform/isoamyl alcohol $(25: 24: 1)$ and once with chloroform/isoamyl alcohol $(24: 1)$ alone. DNA was subsequently precipitated by adding $10 \mu \mathrm{l}$ of $5 \mathrm{M} \mathrm{NaCl}$ plus $1 \mathrm{ml}$ of ice-cold $100 \%$ ethanol and incubating at $-70^{\circ} \mathrm{C}$ for $>20 \mathrm{~min}$. DNA was collected by centrifugation, dried on a Savant Speed Vac (Savant Instruments, Inc., Holbrook, NY) for 20 min with mild heating and resuspended by adding $30 \mu \mathrm{l}$ TE buffer and $1 \mu \mathrm{l} 10 \mathrm{mg} / \mathrm{ml}$ DNase-free RNase A to the tube and incubating overnight at $37^{\circ} \mathrm{C}$. DNA concentrations were determined spectrophotometrically using the absorbance at $260 \mathrm{~nm}$. Ratios of absorbance at $260 \mathrm{~nm} / 280 \mathrm{~nm}$ consistently gave values of $\approx 1.8$ reflective of high purity of DNA.

\section{Preparation of thymocyte nuclear extract}

Thymocyte nuclear extract was prepared as previously described (Cidlowski, 1982; Schwartzman et al, 1991). Briefly, male SpragueDawley rats (100-250 g body weight) were bilaterally adrenalectomized at least 5 days prior to use and maintained on $0.85 \% \mathrm{NaCl}$ and rat chow ad libitum. Four hours prior to sacrifice, rats were injected i.p. with $5 \mathrm{mg} / \mathrm{Kg}$ body weight of the synthetic glucocorticoid dexamethasone suspended by sonication in phosphate buffered saline. Previous studies from our laboratory have shown that this paradigm results in $\approx 50 \%$ of the genome degraded while maintaining a high cellular viability $(\approx 98 \%)$ (Compton and Cidlowski, 1986). Following a $4 \mathrm{~h}$ in vivo exposure period, rats were killed by decapitation and the thymus removed and placed in ice-cold PBS. Thymocytes were released from the tissue by mincing with scissors followed by gentle homogenization in a loose fitting Kontes no. 22 glass/glass homogenizer (Kontes Co., Vineland, $\mathrm{NJ}$ ) on ice. Suspensions were filtered through $202 \mu \mathrm{m}$ Nitex mesh (Tetko, New York, NY) and pelleted at $4^{\circ} \mathrm{C}$. Cells were then washed once in icecold PBS and the plasma membranes lysed $\left(10 \mathrm{mM} \mathrm{MgCl}_{2}, 0.25 \%\right.$ Nonidet $\mathrm{P}-40)$. Nuclei were pelleted and resuspended in extraction buffer ( $300 \mathrm{mM} \mathrm{NaCl}, 1 \mathrm{mM}$ EDTA, $20 \mathrm{mM}$ Tris ( $\mathrm{pH} 7.4)$; $0.5 \mathrm{ml} /$ 
thymus) and rotated at $4^{\circ} \mathrm{C}$ for $1 \mathrm{~h}$. Extracts were then cleared of debris and endogenous chromatin by ultracentrifugation at $165000 \times g$ for $1 \mathrm{~h}$ at $4^{\circ} \mathrm{C}$. Following this centrifugation, the supernates were removed and protein concentrations determined by the method of Bradford (Bradford, 1976). Extracts were aliquoted to avoid repeated freeze/thaw cycles and stored at $-70^{\circ} \mathrm{C}$ until used.

\section{Electrophoresis}

For conventional static-field electrophoretic analysis $1.8 \%$ agarose gels were submerged in $0.5 \times$ TPE $(40 \mathrm{mM}$ Tris-phosphate, $4 \mathrm{mM}$ EDTA) and $15 \mu \mathrm{g}$ of HeLa DNA added per lane. An electric field was applied for $3.25 \mathrm{~h}$ with constant voltage $(80 \mathrm{~V})$. For pulsed field analysis a $2.0 \mathrm{~mm}$ thick slice was cut from the preparatory agarose plug and equilibrated in $50 \mathrm{ml}$ of $0.5 \times$ TBE buffer $(89 \mathrm{mM}$ Tris, $89 \mathrm{mM}$ boric acid, $2.5 \mathrm{mM}$ EDTA) for $>3 \mathrm{~h}$. To insure that these conditions did not result in significant loss of smaller DNA fragments, size standards (Hind III digest of $\lambda$ DNA or $\lambda$ concatamers) were encapsulated in agarose and processed in an identical manner as experimental samples (Figure 4A-Lane 1 and 2). These standards were then electrophoresed and compared to non-processed standards (Figure $4 A$-lane 3 and 4). As shown in Figure 4A, no significant losses of DNA fragments $\geqslant 6.6 \mathrm{~Kb}$ were seen during processing. To prepare the gel, slices were placed against a gel comb and $1 \%$ molten agarose added and solidified around the plugs. The comb was removed and the gel placed in a Clamped Homogenous Electric Field (CHEF) pulsed field system (Bio-Rad Laboratories, Hercules, CA) filled with $0.5 \times$ TBE and allowed to equilibrate to $14^{\circ} \mathrm{C}$. The gel was then electrophoresed for $19 \mathrm{~h}$ at $6.0 \mathrm{~V} / \mathrm{cm}$ with a linear switch interval ramp from $0.5 \mathrm{~s}$ to $45.0 \mathrm{~s}$. The parameters were chosen to optimally separate DNA fragments ranging from 10-500 Kb ((Birren and Lai, 1993), E. Lai, personal communication, information also available from Bio-Rad). As shown in Figure $4 \mathrm{~A}$, these parameters retained fragments in the gel as small as $6.6 \mathrm{~Kb}$. To insure that these parameters provide a linear separation of fragments in the target size, the mobility of the size standards shown in Figure 4A were plotted as a function of size (Figure 4B). From this graph the linear range of separation can be directly read off $(\approx 50-$ $500 \mathrm{~Kb}$ ) (Birren and Lai, 1993). Size standards also included chromosomes from $S$ cerevisiae and $8-48 \mathrm{~Kb}$ standards obtained from Bio-Rad. Following electrophoresis, both pulsed field and conventional gels were stained with $1 \mathrm{mg} / \mathrm{ml}$ ethidium bromide and photographed (Polaroid type 55 film) using UV transillumination.

\section{References}

Arends MJ, Morris RG and Wyllie AH (1990) Apoptosis: The role of the endonuclease. Am J Pathol. 136: 593-608

Barry MA and Eastman A (1993) Identification of deoxyribonuclease II as an endonuclease involved in apoptosis. Arch Biochem Biophys. 300: 440-450

Beere HM, Chresta CM, Alejoherberg A, Skladanowski A, Dive C, Larsen AK and Hickman JA (1995) Investigation of the mechanism of higher order chromatin fragmentation observed in drug-induced apoptosis. Mol Pharmacol. 47: 986996

Bicknell GR and Cohen GM (1995) Cleavage of DNA to large kilobase pair fragments occurs in some forms of necrosis as well as apoptosis. Biochem Biophys Res Commun. 207: 40-47

Birren B and Lai E (1993) Pulsed Field Gel Electrophoresis: A Pratical Guide. San Diego, CA: Academic Press, Inc., p

Boone DL, Yan W and Tsang BK (1995) Identification of a deoxyribonuclease I-like endonuclease in rat granulosa and luteal cell nuclei. Biol Reprod. 53: 10571065

Bortner CD Oldenburg NBE and Cidlowski JA (1995) The role of DNA fragmentation in apoptosis. Trends Cell Biol. 5: 21-26
Bradford MM (1976) A rapid and sensitive method for the quantitation of microgram quantities of protein utilizing the principle of protein-dye binding. Anal Biochem. 72: $248-254$

Brown DG, Sun X-M and Cohen GM (1993) Dexamethasone-induced apoptosis involves cleavage of DNA to large fragments prior to internucleosomal fragmentation. J Biol Chem. 268: 3037-3039

Cain KS, Inayat-Hussain H, Kokileva L and Cohen GM (1995) Multi-step DNA cleavage in rat liver nuclei is inhibited by thiol reactive agents. FEBS Lett. 358 : $255-261$

Cain KS, Inayat-Hussain H, Wolfe JT and Cohen GM (1994) DNA fragmentation into $200-250$ and/or 30-50 kilobase pair fragments in rat liver nuclei is stimulated by $\mathrm{Mg}^{2+}$ alone and $\mathrm{Ca}^{2+} / \mathrm{Mg}^{2+}$ but not by $\mathrm{Ca}^{2+}$ alone. FEBS Lett. 349:385-391

Cidlowski JA (1982) Glucocorticoids stimulate ribonucleic acid degradation in isolated rat thymic lymphocytes in vitro. Endocrinology. 111: 184-190

Cohen GM, Sun X-M, Fearnhead H, MacFarlane M, Brown DG, SRT and Dinsdale D (1994) Formation of large molecular weight fragments of DNA is a key committed step of apoptosis in thymocytes. J Immunol. 153: 507-516

Cohen JJ and Duke RC (1984) Glucocorticoid activation of a calcium-dependent endonuclease in thymocyte nuclei leads to cell death. J Immunol. 132: 38-42

Compton MM and Cidlowski JA (1986) Rapid in vivo effects of glucocorticoids on the integrity of rat lymphocyte genomic deoxyribonucleic acid. Endocrinology. 118: $38-45$

Eastman A (1994) Deoxyribonuclease II in apoptosis and the significance of intracellular acidification. Cell Death Differ, 1:7-10

Filipski J, Leblance J, Youdale T, Sikorska M and Walker PR (1990) Periodicity of DNA folding in higher order chromatin structures. EMBO J. 9: 1319-1327

Gaido ML and Cidlowski JA (1991) Identification, purification, and characterization of a calcium-dependent endonuclease (NUC18) from apoptotic rat thymocytes: NUC18 is not histone $\mathrm{H}_{2}$ B. J Biol Chem. 266: 18580-18585

Gromova II, Nielsen OF and Razin SV (1995) Long-range fragmentation of the eukaryotic genome by exogenous and endogenous nucleases proceeds in a specific fashion via preferential DNA cleavage at matrix attachment sites. J Biol Chem. 270: $18685-18690$

Häcker $G$ and Vaux DL (1995) The medical significance of physiological cell death. Med Res Rev 15: 299-311

Hewish DR and Burgoyne LA (1973) Chromatin substructure. The digestion of chromatin DNA at regularly spaced sites by a nuclear deoxyribonuclease. Biochem Biophys Res Commun. 52: 504-510

Hughes FM Jr and Cidlowski JA (1994) Apoptotic DNA Degradation: Evidence for Novel Enzymes. Cell Death Differ. 1:11-17

Kataoka A, Kubota M, Wakazono Y, Okuda A, Bessho R, Lin YW, Usami I, Akiyama Y and Furusho K (1995) Association of high molecular weight DNA fragmentation with apoptotic or non-apoptotic cell death induced by calcium ionophore. FEBS Lett. 364: 264-267

Kokileva L (1994) Multi-step chromatin degradation in apoptosis. Int Arch Allergy Immunol. 105: 339-343

Kokileva L (1995) Comparative study of induction of endogenous DNA degradation in rat liver nuclei and intact thymocytes. Comp Biochem Physiol Biochem Mol Biol. 111: $35-43$

Kokileva LB (1979) DNA degradation in isolated rat liver nuclei. Molec Biol Rep. 5 : $171-174$

Laemmli UK, Kass E, Polijak E and Adachi Y (1992) Scaffold associated regions: cisacting determinants of chromatin structural loops and functional domains. Curr Opin Genet Dev. 2: 275-285

Lazebnik YA, Cole S, Cooke CA, Nelson WG and Earnshaw WC (1993) Nuclear events of apoptosis in vitro in cell-free mitotic extracts: a model system for analysis of the active phase of apoptosis. J Cell Biol. 123: 7-22

McConkey DJ, Hartzell P, Amador-Pérez JF, Orrenius S and Jondal M (1989a) Calcium-dependent killing of immature thymocytes by stimulation via the $\mathrm{CD} 3 / \mathrm{T}$ cell receptor complex. J Immunol. 143: 1801-1806

McConkey DJ, Hartzell P, Nicotera P and Orrenius S (1989b) Calcium-activated DNA fragmentation kills immature thymocytes. FASEB. 3: 1843-1849

Mirkovich J, Mirault ME and Laemmli UK (1984) Organization of higher order chromatin loop-domain: specific DNA attachment sites on the nuclear scaffold. Cell. 39: 223-232

Montague JW, Gaido ML, Frye C and Cidlowski JA (1994) A Calcium-dependent nuclease from apoptotic rat thymocytes is homologous with cyclophilin: Recombinant cyclophilins A and B exhibit nuclease activity. J Biol Chem. 269: 18877-18880 
Montague JW, Hughes FM Jr and Cidlowski JA (1996) Purified recombinant cyclophilins $A, B$, and $C$ facilitate nucleic acid degradation independently of peptidylprolyl cis-trans isomerase activity: potential roles in apoptosis. J Biol Chem (in press)

Nieto MA and Lopez-Rivas A (1989) IL-2 protects T lymphocytes from glucocorticoidinduced DNA fragmentation and cell death. J Immunol. 143: 4166-4170

Oberhammer F, Wilson JW, Dive C, Morris ID, Hickman JA, Wakeling AE, Walker PR and Sikorska M (1993) Apoptotic death in epithelial cells: cleavage of DNA to 300 and/or $50 \mathrm{~kb}$ fragments prior to or in the absence of internucleosomal fragmentation. EMBO J. 12: 3679-3684

Ormerod MG, O'Neill CF, Robertson D and Harrap KR (1994) Cisplatin induces apoptosis in a human ovarian carcinoma cell line without concomitant internucleosomal degradation of DNA. Exp Cell Res. 211: 231-237

Peitsch MC, Polzar B, Stephan H, Crompton T, MacDonald HR, Mannherz HG and Tschopp J (1993) Characterization of the endogenous deoxyribonuclease involved in nuclear DNA degradation during apoptosis (programmed cell death). EMBO J. 12: 371-377

Peitsch MC, Polzar B, Tschopp J and Mannherz HG (1994) About the involvement of deoxyribonuclease I in apoptosis. Cell Death Differ. 1: 1-6

Saitoh Y and Laemmli UK (1994) Metaphase chromosome structure: bands arise from a differential folding path of the highly AT-rich scaffold. Cell. 76: 609-622

Schwartzman RA and Cidlowski JA (1991) Internucleosomal deoxyribonucleic acid cleavage activity in apoptotic thymocytes: detection and endocrine regulation. Endocrinology. 128: 1190-1197
Schwartzman RA and Cidlowski JA (1993a) Apoptosis: The biochemistry and molecular biology of programmed cell death. Endocrine Rev. 14: 133-151

Swhwartzman RA and Cidlowski JA (1993b) Mechanism of tissue-specific induction of internucleosomal deoxyribonucleic acid cleavage activity and apoptosis by glucocorticoids. Endocrinology. 133: 591-599

Sun X-M and Cohen GM (1994) $\mathrm{Mg}^{2+}$-dependent cleavage of DNA into kilobase pair fragments is responsible for the initial degradation of DNA in apoptosis. J Biol Chem. 269: 14857-14860

VanderbiltJN, Bloom KS and Anderson JN (1982) Endogenous nuclease. Properties and effects on transcribed genes in chromatin. J Biol Chem. 257: 13009-13017

Walker PR, Kokileva L, LeBlanc J and Sikorska M (1993) Detection of the initial stages of DNA fragmentation in apoptosis. BioTechniques. 15: 1032-1040

Walker PR, Pandey S and Sikorska M (1995) Degradation of chromatin in apoptotic cells. Cell Death Differ. 2: $97-104$

Walker PR and Sikorska M (1986) Modulation of the sensitivity of chromatin to exogenous nucleases: implications for the apparent increased sensitivity of transcriptionally active genes. Biochemistry. 25: 3839-3845

Walker PR, Weaver VM, Lach B, LeBlanc J and Sikorska M (1994) Endonuclease activities associated with high molecular weight and internucleosomal DNA fragmentation in apoptosis. Exp Cell Res. 213: 100-106

Wyllie AH (1980) Glucocorticoid-induced thymocyte apoptosis is associated with endogenous endonuclease activation. Nature. 284: 555-556 